\title{
Anatomical Roots of Acupuncture and Chinese Medicine
}

\author{
Claus C. Schnorrenberger \\ Lifu International College of Chinese Medicine, Basel, Switzerland
}

\section{Keywords}

Classical sources of acupuncture anatomy in ancient China .

Organ names in ancient Chinese texts . Anatomical nomenclature for acupuncturists · Safer acupuncture techniques - Reliable foundation for acupuncture research and practice of Chinese medicine

\section{Summary}

The earliest historic reference to a dissection of a human cadaver is found in the biography of Emperor Wang Mang 王莽 who in 16 C.E. ordered the medical dismembering of the body of a rebel named Wang Sun-Ching (occidental anatomy began only 1,500 years later). Measurements were made of his internal organs, and bamboo rods were inserted into his blood vessels in order to discover where they begin and where they end for the purpose of a better understanding of how to cure diseases. Similar anatomical dissections are mentioned in chapter 12 of the Huang-Di Nei-Jing Ling-Shu 黄帝內經靈樞, entitled Jing-Shui 經水. The ancient Chinese characters for body dissections given here are the same as in modern Chinese anatomy, namely Jie-Pou 解剖. The courses of the pathways as laid out in chapter 10 of the Ling-Shu Jing could well be the result of such dissections; they are elementary for acupuncture and Chinese medicine. Otherwise it cannot be explained why ancient $C$ hinese physicians were able to denominate the respective viscera properly with names still in use today and how they could locate them topographically in their correct position as well as linking them to the vessel pathways leading to the periphery of the human body. The majority of Western acupuncturists adhere to far-fetched assumptions about 'meridians', 'channels', 'points', and 'energy' which have never existed in China. Western acupuncture thus relies on a basic logical error, a so-called Wrong Beginning (Proton pseudos $\pi \rho \tilde{\omega} \tau o v ~ \psi \varepsilon \tilde{\omega} \delta \circ \varsigma)$. That is why modern acupuncture finally needs an anatomical nomenclature for daily practice and scientific research including all the structures involved, which are still the same as 2,000 years ago.

\author{
Schlüsselwörter \\ Klassische Akupunkturanatomie im alten China . Organnamen in \\ historischen chinesischen Texten · Anatomische Nomenklatur für \\ Akupunkteure - Bessere Akupunkturtechniken · Zuverlässigere \\ Grundlagen für Forschung und Praxis in der Chinesischen Medizin
}

\section{Zusammenfassung}

Anatomische Wurzeln der Akupunktur und der Chinesischen Medizin Die historisch früheste Dokumentation der Sektion einer menschlichen Leiche findet sich in der Biografie des chinesischen Kaisers Wang Mang 王莽, der im Jahre $16 \mathrm{n}$. Chr. die medizinische Zergliederung des Kadavers eines hingerichteten Rebellen namens Wang Sun-Ching anordnete (die abendländische Anatomie begann rund 1500 Jahre später). Messungen an seinen inneren Organen wurden durchgeführt und Bambusruten wurden in seine Blutgefässe eingeführt, um zu erkunden, wo letztere beginnen und wo sie enden, um ein besseres Verständnis für die Entstehung und Behandlung von Krankheiten zu erhalten. Ähnliche anatomische Sektionen werden im Buch Huang-Di Nei-Jing Ling-Shu 黄帝內經靈樞（Ling-Shu Jing 霝樞經), 12. Kapitel Jing-Shui 經水, erwähnt. Die klassischen chinesischen Schriftzeichen, die hier für die anatomische Technik stehen, heissen Jie-Pou 解剖; es sind dieselben Zeichen, die in China noch immer für das medizinische Fach der Anatomie verwendet werden. Die Verläufe der BlutgefässBahnen, die im 10. Kapitel desselben Werkes beschrieben werden, sind für die chinesische Akupunktur und Medizin grundlegend. Sie sind vermutlich das Ergebnis solcher anatomischer Sektionen. Auf andere Weise ist es unerklärlich, warum die frühen chinesischen Mediziner die verschiedenen inneren Organe mit den richtigen Namen benannt haben, die auch gegenwärtig noch verwendet werden, und warum sie die Organe topografisch korrekt platzieren und sie den an die Peripherie des Organismus führenden Gefässverläufen richtig zuordnen konnten. Westliche Akupunkteure verwenden eine skurrile Terminologie, die «Meridiane», «Kanäle», «Punkte» und eine «Energie» postuliert, die in China niemals existiert haben. Die westliche Akupunktur stützt sich somit auf einen falschen Anfang (Proton pseudos $\pi \rho \tilde{\omega} \tau o v \psi \varepsilon \varepsilon \tilde{\omega} \delta \circ \varsigma)$, der seit Aristoteles als Kardinalfehler in der Logik gilt. Deshalb benötigen wir dringend eine anatomische Nomenklatur

$\begin{array}{ll}\text { KARGER } & \text { @ 2013 S. Karger GmbH, Freiburg } \\ \text { 1015-0684/13/0252-0110\$38.00/0 } \\ \begin{array}{l}\text { Fax +49 761 } 4520714 \\ \begin{array}{l}\text { Information@Karger.com } \\ \text { www.karger.com }\end{array}\end{array} & \begin{array}{l}\text { Accessible online at: } \\ \text { www.karger.com/szg }\end{array}\end{array}$

Professor h.c. (China Medical University, Taichung, Taiwan, Rep. China)

Dr. med. Claus C. Schnorrenberger, M.D.

Lifu International College of Chinese Medicine

Karl Jaspers-Allee 8, 4052 Basel, Switzerland

lifu@gmx.ch

www.lifu-chinesischemedizin.ch 
für die tägliche Akupunkturpraxis und für wissenschaftliche Untersuchungen, die unter Verwendung der genannten falschen Begriffe purer Nonsens bleiben. Dies wäre eine Nomenklatur, in der sämtliche morphologischen Strukturen, die noch dieselben sind wie vor rund 2000 Jahren, original und richtig beschrieben werden.

\section{Mots-clés}

Sources classiques d'anatomie acupuncturale en Chine ancienne . Noms des organes dans les textes de la Chine ancienne . Nomenclature anatomique pour les acupuncteurs - Techniques d'acupuncture plus sûres · Fondements fiables pour la recherche en matière d'acupuncture et sa pratique de la médecine chinoise

\section{Résumé}

\section{Racines anatomiques de l'acupuncture et de la médecine chinoise}

La référence historique la plus ancienne d'une dissection de cadavre humain se trouve dans la biographie de l'empereur Wáng Măng 王莽 qui ordonna en 16 ap. J.-C. le démembrement médical du corps d'un rebelle nommé Wang Sun-Ching (I'anatomie occidentale ne commença que 1500 ans plus tard). Des mesures furent prises à partir de ses organes internes et des tiges de bambou insérées dans ses vaisseaux sanguins pour découvrir où ils commençaient et se terminaient afin de mieux comprendre comment soigner les maladies. Des dissections anatomiques semblables sont mentionnées au chapitre 12 du Classique interne de l'empereur Jaune (Huang-Di Nei-Jing LingShu 黄帝內經靈樞) intitulé Jing-Shui 經水. Les caractères chinois anciens utilisés pour parler des dissections corporelles dans l'ouvrage sont les mêmes qu'en anatomie chinoise moderne, à savoir Jie-Pou 解剖. Le réseau des voies décrit au chapitre 10 du Ling-Shu Jing pourrait bien résulter de ces dissections; il est élémentaire en acupuncture et médecine chinoise. Autrement, on ne peut pas expliquer pourquoi les médecins de la Chine ancienne étaient capables de nommer correctement les viscères respectifs avec les dénominations encore en usage aujourd'hui, et comment ils pouvaient les situer correctement sur un plan topographique et les associer aux voies vasculaires menant à la périphérie du corps humain. La majorité des acupuncteurs occidentaux adhèrent à des hypothèses fantaisistes sur les «méridiens», les «canaux», les «points» et l'«énergie» qui n'ont jamais existé en Chine. L'acupuncture occidentale repose donc sur une erreur logique de base, le

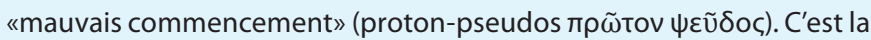
raison pour laquelle l'acupuncture moderne a finalement besoin d'une nomenclature anatomique pour la pratique quotidienne et la recherche scientifique comprenant toutes les structures impliquées qui restent les mêmes qu'il y a environ 2000 ans.

\section{Anatomy in Early China}

Dissections of human bodies were seldom practised in ancient China because the human body was considered sacred. Confucius had said in his Filial Classic: 'Our body with skin and hair comes from our parents. We must not mutilate it 身體髮膚受之父母不可毀傷' [1].

Accordingly, a systematic anatomical research could not yet be developed in the early days. However, the wish to uncover the secrets of nature could not be completely suppressed. Medical persons as well as laymen have tried at different times to find out the exact conditions of the internal organs.

The book Huang-Di Nei-Jing Ling-Shu 黃帝內經靈樞 states in its twelfth chapter, entitled Vessel Rivers (JingShui 經水) [2]:

\footnotetext{
'It is beyond human capacity to measure the height of the sky or the extension of the earth. But it is easy to obtain surface measurements of a human being who is 8 feet tall. After death his body may be dissected to get a general idea of the appearance, the size and the capacity of his viscera, to measure the length of his blood vessels, evaluate the quantity and condition of the blood and the Qi $(X u e Q i$ 血氣)'.
}

The earliest historic reference to dissections of human cadavers is found in the Han Annals 漢書. Here, in the biography of the emperor Wang Mang 王莽, it is written that the emperor ordered the dissection of the body of a rebel named Wang Sun-Qing 王孫慶 who had been caught by the imperial army. The dissection was performed in 16 C.E. by the court physician Shang Fang in association with a 'skilful butcher' [3].

The text continues: 'Measurements were then made of the internal organs and bamboo rods were inserted into the blood vessels in order to discover where they begin and where they end for the purpose of a better understanding of how to cure diseases' [3].

As it was conducted by a doctor, this perhaps was the first real experiment connected with anatomical dissections in medical history. A similar procedure is mentioned in chapter 12 of the acupuncture classic Huang-Di Nei-Jing Ling-Shu referred to above. The objective of the investigation was to determine the condition of the human viscera, the blood, and the blood vessels. Emperor Wang Mang was obviously interested in anatomy. He was a reformer emperor. As he probably hoped to walk in the footsteps of his legendary prehistoric forerunner, he adopted the title of Xin Huang D $i$ 新黃帝, 'New Yellow Emperor'. An interesting accompaniment of his reforms was the emphasis on the study of ancient literature. One of his court scholars, Liu Hsin, edited many ancient texts on literature, religion, politics, and medicine. We may speculate whether a prototype of the famous medical book Huang-Di Nei-Jing has been among those texts $[2,4]$. 


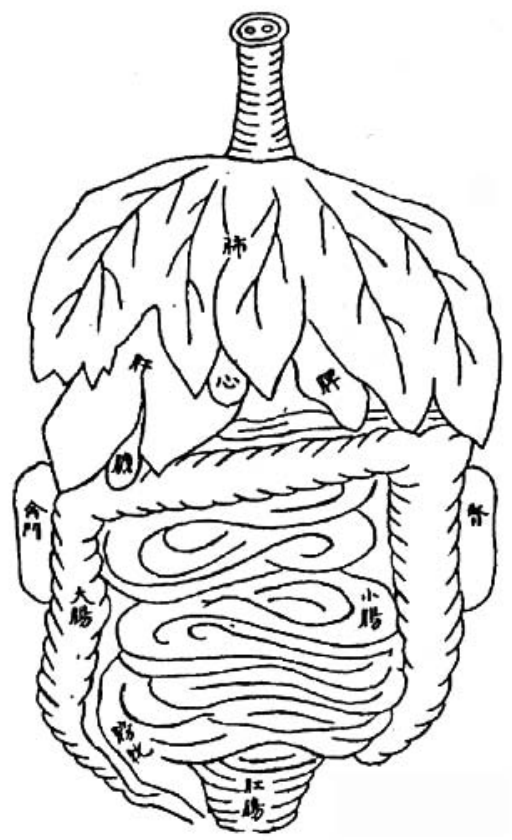

Fig. 1. Front view of $\mathrm{OuXi-Fan's} \mathrm{'Five} \mathrm{inter-}$ nal organs' 歐希范五藏圖 (visible are the trachea, lung, heart, spleen, liver, gallbladder, kidney, small intestine, large intestine, anal canal) [8].

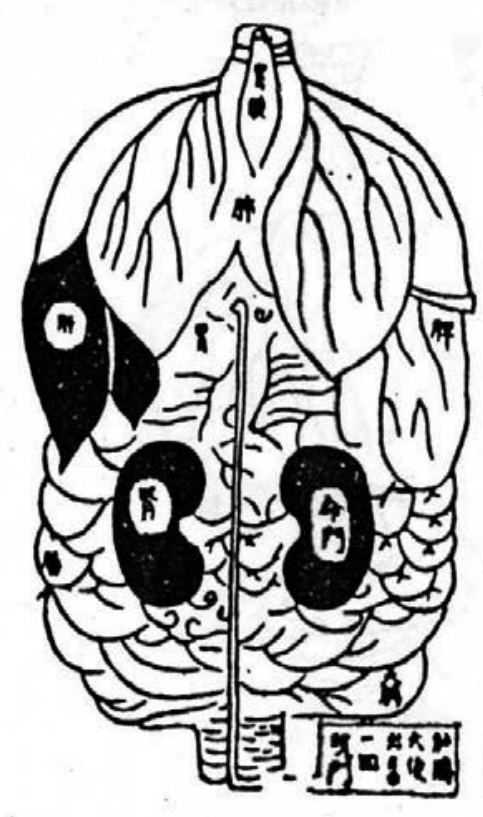

Fig. 2. Dorsal view of a human torso with spleen (blackened on left side), lung, stomach, and left and right kidneys (blackened). Illustration from about 938-943 [8] (many of the labelled Chinese characters in the cited figures are not clearly recognizable, probably due to the quality of the original figures).

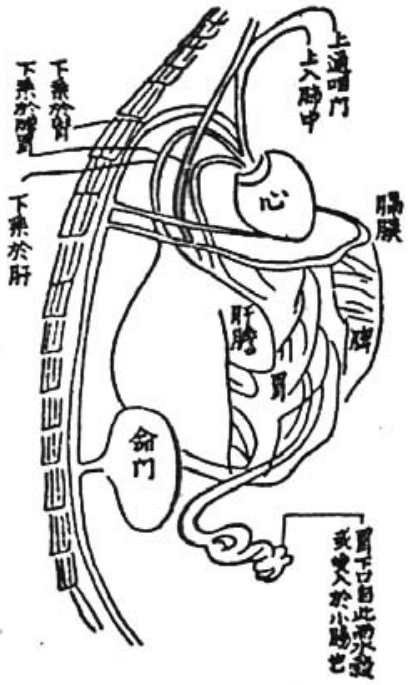

Fig. 3. Illustration from the book 'Wan An Fang'萬安方 (Ten thousand Helpful Prescriptions) published in 1315: The heart with great vessels leading to the viscera, diaphragm, liver, spleen, right kidney ('MingMen 命門'), and stomach [8].
In the book Pin Tui Lu 宾退錄 from the Northern Song Dynasty (960-1127 C.E.) the following report is given [3]:

'In Kuang-Su the robber Ou Xi-Fan 歐希范 and his followers were killed, and within two days 56 persons were dissected. The coroner $\mathrm{Wu}$ Jian 吳簡 inspected the bodies carefully and made drawings of them' [5].

This mass dissection is mentioned several times by other historic sources. The drawings were known as 'Ou Xi-Fan's Pictures of the Five Viscera' 歐希范五藏圖. The captives were killed, their abdomens opened, and the kidneys and intestines cut out. The blood vessels, ligaments, tendons, muscles, organs, and viscera of the bodies were gathered together and examined (fig. 1-3). In his book 'History of Medicine' (1964) the Japanese medical historian Teizo Ogawa mentioned the reprint of Ou Xi-Fan's Pictures of the Five Viscera 歐希范五藏圖 in an ancient Japanese work, entitled Ton-i-sho, written and published by Shozen Kajiwara between 1302 und 1304 [5, 6].

During the Chong-Ning 崇寧 period (1102-1106) of the Song Dynasty many bandits were executed at Soochow. With the help of medical doctors and artists, the prefect $L i$ Yi-Heng (李夷行) personally examined the viscera, and physicians and painters assisted him by making detailed drawings of them. These pictures were edited by Yang-Jie (楊介) and called the Atlas of Truth (Cun Zhen Tu 存貞圖); they were thought to be superior to those of $\mathrm{OuXi-Fan}$. For centuries this book was considered invaluable for teaching the members of the medical profession in China.

Since only cadavers of robbers and bandits were used for anatomical dissections, it gave rise to the erroneous assumption that dissections were simply a kind of punishment for criminals. Consequently, no one in China was willing to donate his body for scientific purposes [7]. Three historic Chinese illustrations of dissected cadavers are depicted in figures 1-3 [8].

\section{Ancient Chinese Body Dissections and Modern Anatomy}

Anatomical dissections in ancient China are mentioned in chapter 12 of the Ling-Shu Jing, entitled Jing-Shui 經水. Here, the imperial physician Q $i$ Bo 歧伯 explains the fundamental structures of the human organism to the emperor Huang D $i$ 黃帝. The physician says: 'Qi si ke jie pou 其死可解剖', which can be translated as: 'After someone has died his body can be anatomically dissected (for medical investigation)' [2].

It should be noticed that the modern Chinese characters for 'anatomy' are still the same, namely jie pou 解剖. Accordingly, the Chinese term for anatomy stems from this 
passage in the book Ling-Shu Jing. For example, the title of a modern Chinese book on human anatomy which I have used in the following is Tu-Jie Ren-Ti Jie-Pou-Xue Shou-Ce 圖解人體解剖學手冊 [9].

Qi Bo points out that the interior of the body can be judged by measuring the structures on the outside (skin, muscles, bones etc.) of a person, and that the internal organs Zhang Fu 臟腑, their capacity, their contents, and the length of the blood vessels, the quality of the arterial and venous blood including the amount of $Q i$ 氣 can be evaluated by anatomical post mortem dissections. In my view, the courses of the blood vessels, as laid out in chapter 10 of the Ling-Shu Jing, are the result of such dissections. Otherwise, it cannot be understood how the ancient physicians could name the respective viscera properly and how they could locate them in their topographically correct position as well as linking them to the vessel pathways leading to the periphery of the body.

In chapter 31 of the Ling-Shu Jing, entitled Intestines and Stomach (Chang Wei 腸胃), the figures of the following anatomical measurements of the human body are listed:

- distance from the lips to the tongue

- width of the human mouth

- distance from the teeth to the vocal cords (larynx)

- internal volume of the mouth

- weight of the tongue

- length of the tongue

- width of the tongue

- weight of the larynx

- width of the oesophagus

- length of the oesophagus

- length of the stomach

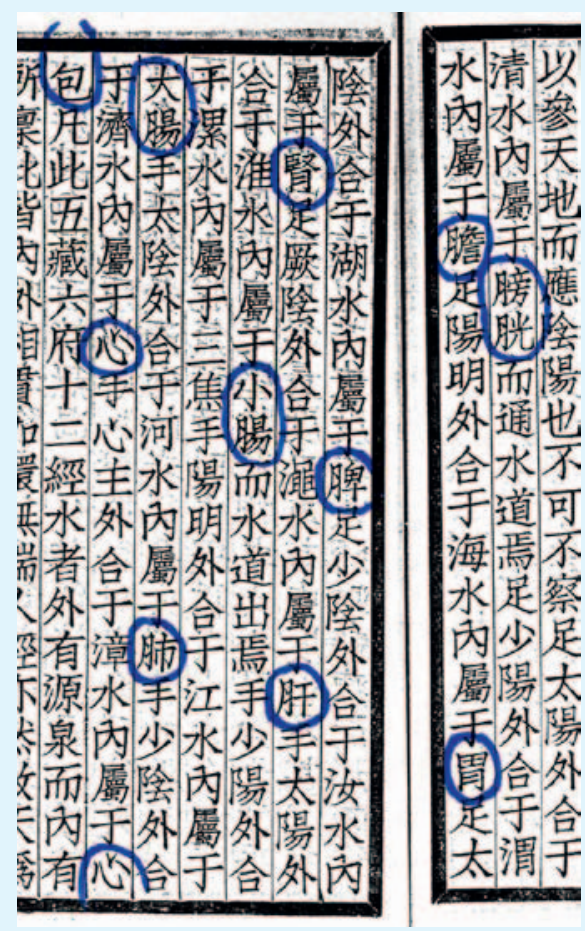

Fig. 4. Two original pages from chapter 12, Vessel Rivers (Jing-Shui 經水), of the Huang-Di NeiJing Ling-Shu [2].
- circumference of the stomach

- diameter of the stomach

- maximum capacity of the stomach

- length of duodenum and jejunum

- circumference of the small intestine

- diameter of the small intestine

- topography of the course of the large intestine

- circumference of the colon descendens

- diameter of the colon descendens

- length of gastrointestinal tract from mouth to anus.

Most of these data come quite close to the modern anatomical understanding [2]. Moreover, the names for anatomical structures (internal organs, muscles, tendons) used by modern Chinese anatomy are still the same names as used in the Ling-Shu Jing (see below).

The eleven internal organs heart, lung, liver, spleen, kidney, pericardium, small and large intestine, gallbladder, stomach, urinary bladder, in addition to the San Jiao (Tripler Burner), which represents the three main levels of the trunk, are expressly mentioned in chapter 12 of the Ling-Shu Jing, entitled Jing Shui 經水 (The Vessel Rivers) (fig. 4).

Here, the respective eleven viscera are the body structures where the blood vessels (or 'channels') either lead to or from where they originate. The Chinese characters for the eleven organs involved are: 膀胱 Pang Guang (urinary bladder), 膽囊 Dan Nang (gallbladder), 胃Wei (stomach), 脾 Pi (spleen), 腎 Shen (kidney), 肝 Gan (liver), 小, 大腸 Chang (small and large intestine), 肺 Fei (lung), 心 Xin (heart), 心包 Xin Bao (pericardium).

These ancient characters are the same organ names as used in modern anatomy and medicine which means that the ancient and modern organs are at least anatomically identical [2].

\section{Early Chinese Embryology}

The basic text of Chinese acupuncture, the Huang-Di Nei-Jing Ling-Shu 黃帝內經靈樞, compiled during the Han dynasties (about 200 B.C.E. until 200 C.E.), has remained vital to this day. It contains a multitude of useful information for the practising physician as well as an amazing amount of contributions to general medical understanding. In its tenth chapter, entitled 'The Pulsating Blood Vessels (Jing Mai 經脈)', the development of the human embryo is described. Here, the Chinese emperor Huang D $i$ explains the generation of the human being with the combination of a female ovum (egg cell) Jing 精 (the modern Chinese term for the female egg cell is Luan $\mathrm{Zi}$ 卵子) with a male sperm (Jing 精). When the two have united, the brain Nao 腦 and the spinal cord Sui 骨遀 (which in my view both correspond to the ectoderm of the three germ layers of embryology) unfold. Then, the bones $G u$ 骨 


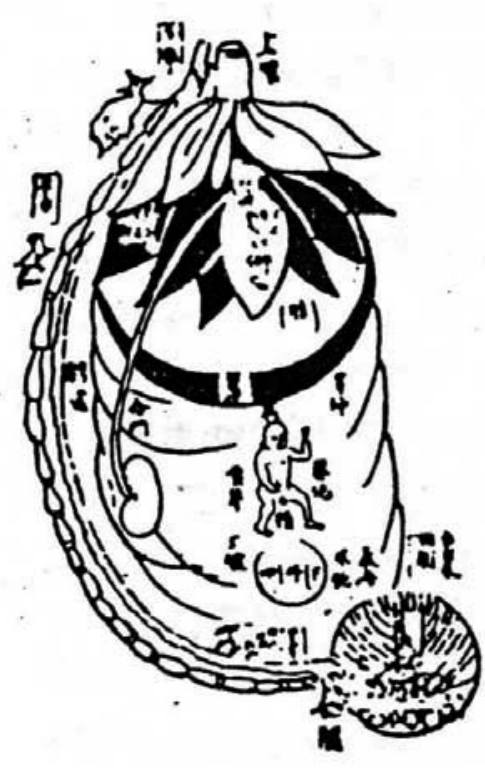

Fig. 5. Fertilisation and embryology according to Chapter 10, Jing Mai, of the Ling-Shu Jing. Showing the pubic hair, the vaginal opening, the embryo, and the right kidney ('Ming-Men 命門'). Drawing from about 938-943 C.E. [8].
Fig. 6. Original page with the onset of chapter 10 from the Ling-Shu Jing explaining the development of the human embryo and the significance of the human blood circulation [2].

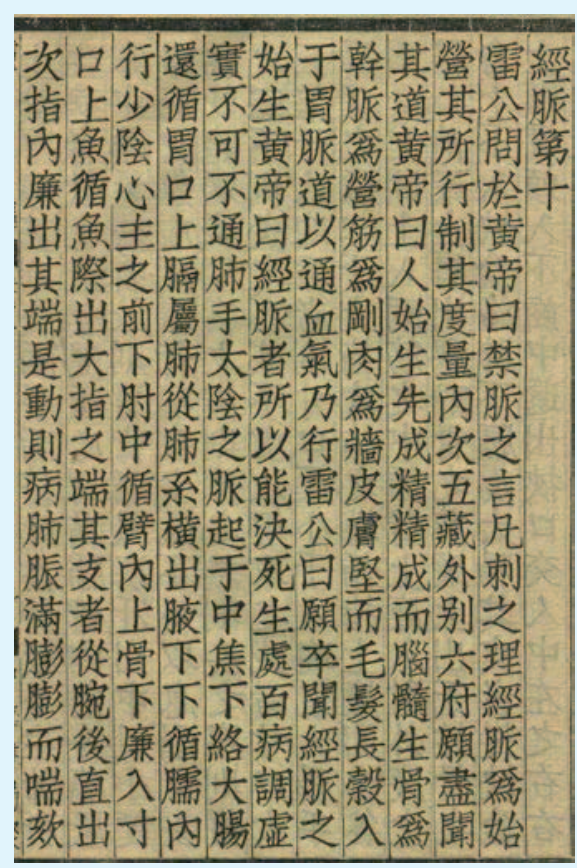

and the blood vessels Mai 脈 containing blood Xue 血 and $Q i$ 氣 come up. The vessels transport nutrients (Ying 營) as well as defence agents of the immune system (Wei 衛). The emperor points out that blood and Qi (Xue-Qi 血氣) circulate continuously within the embryonic vessels without a beginning and an end. Notably, this Chinese source is the first one in medical history referring to the human blood circulation. Thereafter, the tendons Jin 筋 and the muscles Rou 肉 appear. They both protect the internal organs Zang Fu 臟腑. Finally, the skin $P i$ 皮 and the hair Mao $€$ come up, and then the new human being is completed [2] (fig. 5, 6).

In this text, Huang-Di emphasizes that a physician who is familiar with the blood vessels and blood circulation in the organism can determine life or death of a person, diagnose all different sorts of diseases and, as a consequence, can treat and heal them well. For this diagnostic reason, pulse diagnosis was developed and applied in China, namely as a measurement of the intensity of blood flow within the body vessels.

By means of a proper translation of this text the ordered structures, the organs, and the functions of the human embryonic development of the organism become evident. In fact, the vessels of the book Ling-Shu Jing are the vascular, nervous and conductive pathways of the human organism, described here as pulsating blood vessels Jing Mai 經 脈. Because the brain and the spinal cord are mentioned, we may assume that the central nervous system (CNS) plus the peripheral nerves were incorporated in the designation 'vessel 經脈'. Thus, the pathways and bundles of the organism are completely involved. They transmit the effects of needle therapy and of moxibustion (Zhen-Jiu 鍼炎).
Accordingly, the pathways, which in the West have been called 'meridians' or 'channels', appear in a completely new light because they turn out to be the neurovascular bundles of conventional medicine. European sinologists and other non-medical translators of Chinese acupuncture texts have obscured such elementary Chinese medical knowledge due to their medical ignorance. Therefore, they are the ones who must be blamed for the lasting confusion in contemporary Western acupuncture circles. The correct interpretation of the original texts according to early Chinese anatomical studies allows for a relatively simple morphological and physiological identification of the erroneously so-called 'meridians'. It offers, at last, a sensible scientific explanation of the effects of needle insertion, moxa burning, blood-letting, and cupping via the muscles, vascular and nervous structures, including their regulatory centres in the brain and the spinal cord (CNS) $[10,11]$.

\section{'Meridians'}

The Western term 'meridian' originates from geography. Geographic meridians are related to the station of the sun at noon and are named $\mathrm{ZiWuXian}$ 子午綫 in modern Chinese. They are not an aspect of medicine. On the contrary: Immaterial 'meridians' or 'channels' as pretended by westernised acupuncture are in fact the well-known and all along scientifically identified structures of modern anatomy and of conventional orthodox medicine. Chapter 10 of the Ling-Shu Jing explicates that the 12 Jing $M a i$ 經脈 run deep inside the human organism, namely inside the muscles Rou 肉, and that they are not visible on the body surface. 
Accordingly, such original Jing Mai 經脈 have nothing to do with the (more or less) superficial denominations of Western acupuncturists for such body lines and for acupuncture 'points' which are, at best, mnemonic underpinnings for medically retarded brains simulating questionable lines drawn on the surface of the human skin which, in fact, do not exist and have never existed in medical history. Such mystical structures are endlessly dwelled upon by thousands of illiterate Western acupuncturists plus some paramedical Chinese physicians in the West, some of them sinologists, most of them medical laymen, by authors (encouraged by greediness and folly of ill-advised Western publishers) of widely spread acupuncture texts and, consequently, by initiators and interpreters of a westernised 'Foundation of Chinese Medicine' which has nothing to do with authentic roots of Chinese medical history. Listing the names and books of such irresponsible pretenders would result in paying too much tribute to them in the context of this paper.

The Chinese term Jing Mai 經脈 means 'blood vessel'. The radicals and components used in the pictograph Jing 經 are:

- 1. Silk 糸

- 2 . The surface of the body -

- 3. Underground water courses 111

- 4. To examine the underground veins (the respective radical is not 工 Gong, but Ting 壬) [12].

The second pictograph, 脉 Mai or 脈 (㢳, 脉, 血永), is constructed with the components of:
-1. Flesh 肉 $($ 月)

- 2. Blood 血

- 3. A watery stream in the veins 派 $[10,12]$.

Accordingly, the meaning of Jing Mai 經脈 is: 'The silk-like network of blood vessels (veins) running underneath the surface of the body, which can be examined by pulse diagnosis' [12].

These Jing Mai 經脈 vessels include:

- The blood vessels 血脈 Xue Mai,

- the central nervous system with the brain 腦 Nao, and

- the spinal cord 骨遀Sui including the spinal nerves,

- the peripheral nerves 神經系統 Shen Jing Xi Tong,

- other nervous pathways 神經道 Shen Jing Dao, in addition to

- tendons and muscles 筋 (肌肉) Jin (Ji Rou).

The blood vessels (Jing Mai 經脈) transport blood (Xue 血) and oxygen ( $Q i$ 氣), nutrients (Ying 營), immune defence agents ( Wei 衛), and body liquids ( $\mathrm{Jin}-\mathrm{Ye}$ 津液).

A short summary of the vascular design of original Chinese acupuncture:

The Chinese term Jing Mai 經脈 refers to the 'pulsating blood vessels underneath the body surface', deep in the interior of the organism. These Jing Mai 經脈 comprise well-known structures of conventional modern anatomy and physiology, namely:

- The blood vessels in a narrower sense, Xue Mai 血脈,

- the central nervous system with the brain Nao 腦, and

- the spinal cord Sui 骨遀 (in conjunction with the spinal nerves),
Fig. 7. a Korean Copper man constructed about 1600. b Copper man from the MingDynasty (1443). c Original Chinese Copper $\operatorname{man}(1027)$ [11].
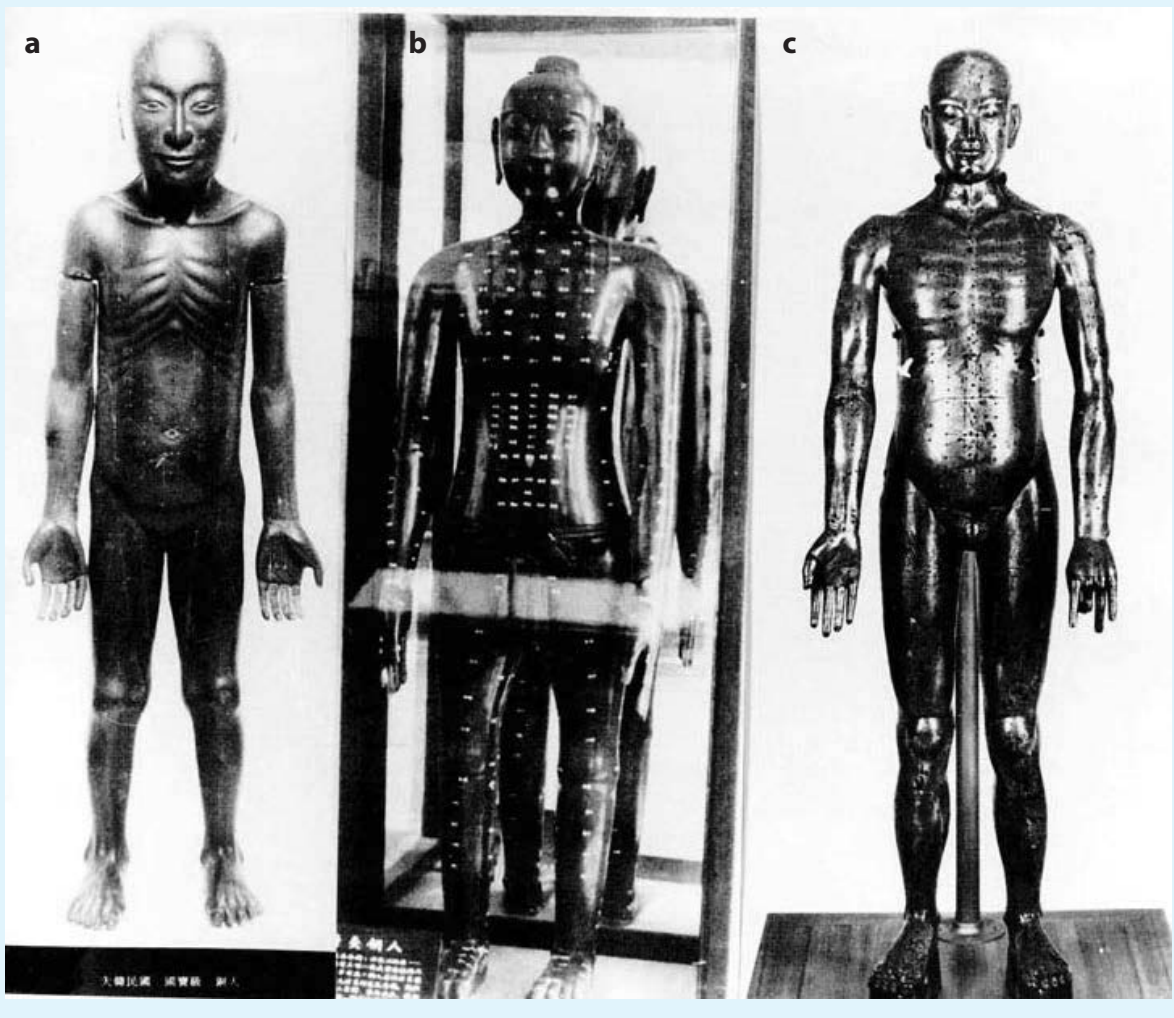


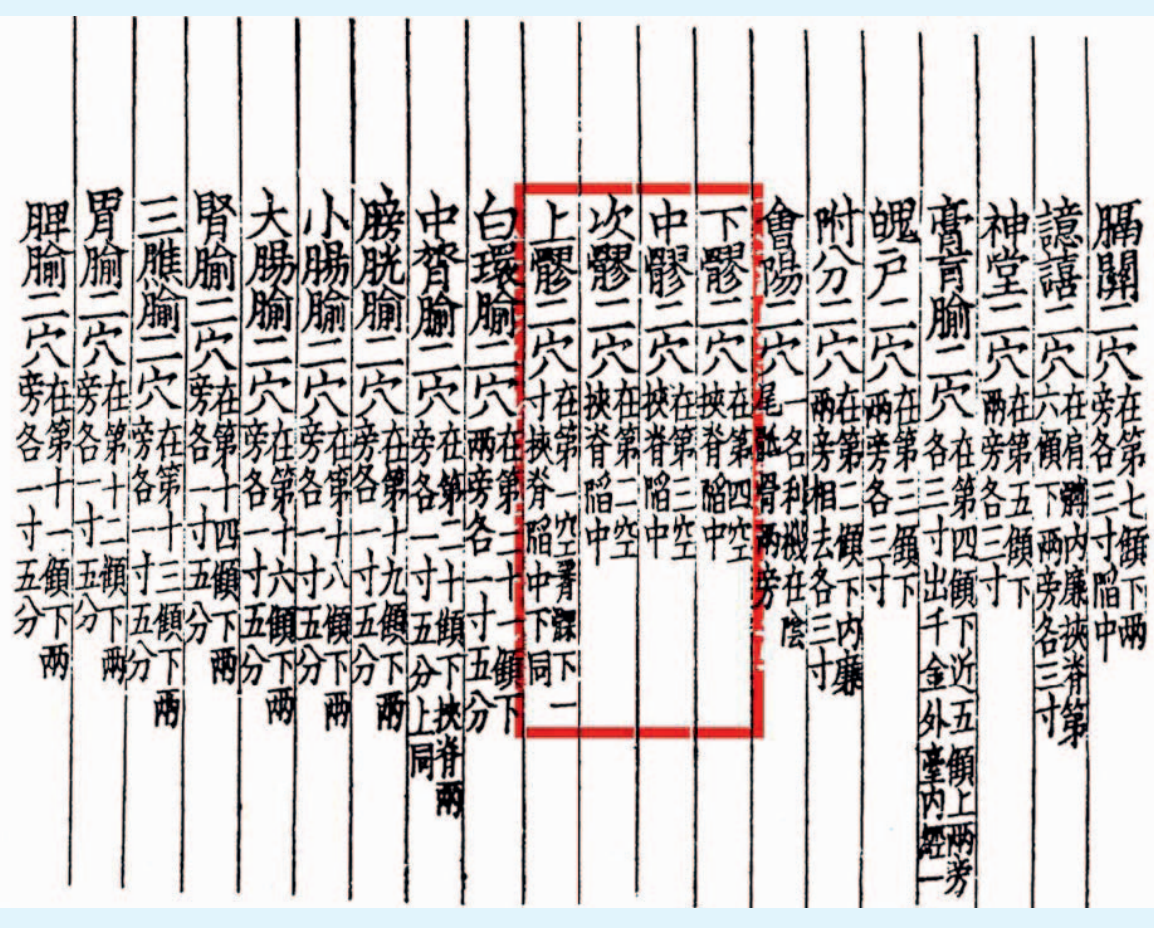

尾各骶日。尾尼内側 偆髈端尾骶其抅, 面

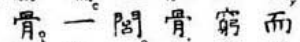
又名一金處成 各掫 名鏼毁督

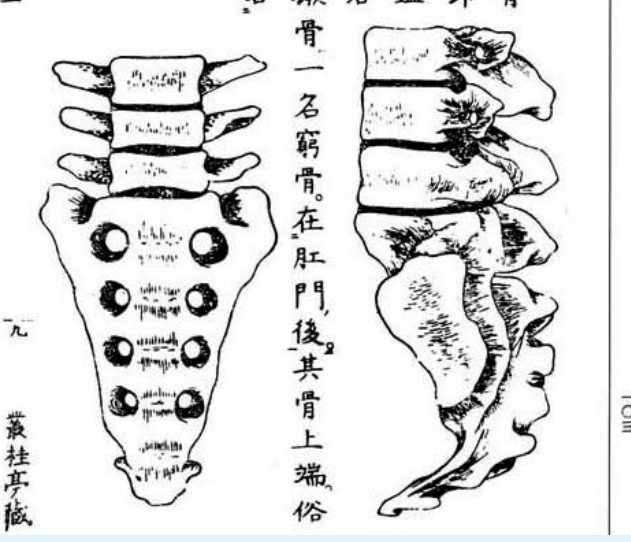

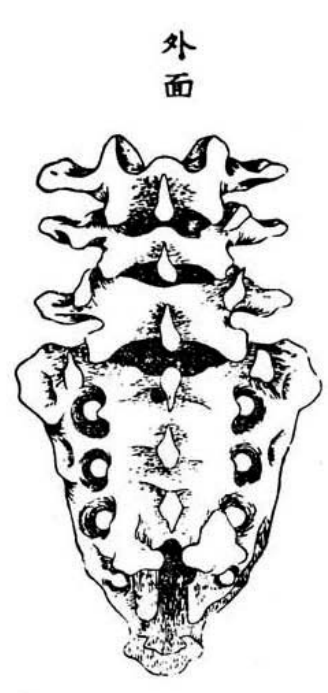

Fig. 8. A page from the Tong-Ren textbook with a description of the topography of the 8 sacral foramina (Ba Liao 八髎) $[15,16]$. The meaning of the pictograph Liao is 'a hole in the bone'. In today's Western terminology the Ba Liao are named 'Points Bladder 31-34' which is a widely meaningless rendering of their original and scientific significance.

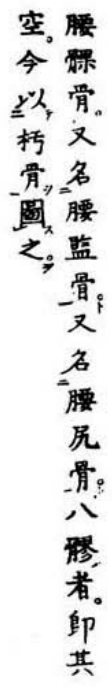

Fig. 9. Illustration of the 8 sacral foramina from the acupuncture book Jing-Xue Hui-Jie 經穴會解 published in Japan in the early 19th century in the Chinese language [17]. The structures depicted are identical with those of the sacral bone given in modern anatomical books, e.g. in Gray's 'Anatomy' [11].
- the peripheral nerves Zhou Bian Shen Jing Dao 周邊神 經道,

- other pathways of the nervous system Shen Jing Xi Tong 神經系統, in addition to tendons Jin 筋 and muscles Ji Rou 肌肉 (explained in detail in chapter 13, Jing-Jin 經筋, of the book Ling-Shu Jing).

The blood vessels (Jing Mai 經脈) transport arterialised blood (Xue Qi 血氣) which is supplied with air and oxygen ( $Q i$ 氣) by breathing, in addition to filling with nutriments (Ying 營), agents of the immune defence (Wei 衛), and body liquids (Jin-Ye 津液) also referred to as water Shui 水. This classical Chinese description corresponds, though roughly and in a preliminary way, with basic facts of modern physiology.

\section{Anatomy in Ancient China and in the West}

In the year 1027, the Imperial physician Wang Wei-Yi 王惟一 constructed the famous Copper Man (Tong-Ren 銅人); sometimes also called Bronze Statue of Acupuncture (fig. 7), by order of the then reigning Song emperor. The statue was meant to be used for teaching acupuncturists and for examining them on needle techniques, topography, and the structures of the human body. It was the oldest model of the human body for medical education in the history of medicine.

The original Copper Man (fig. 7c) is modelled accurately according to modern anatomical standards as stated by the neuro-anatomist Prof. Hongchien Ha, M.D., China Medical University, Taichung, Taiwan, Republic of China. 


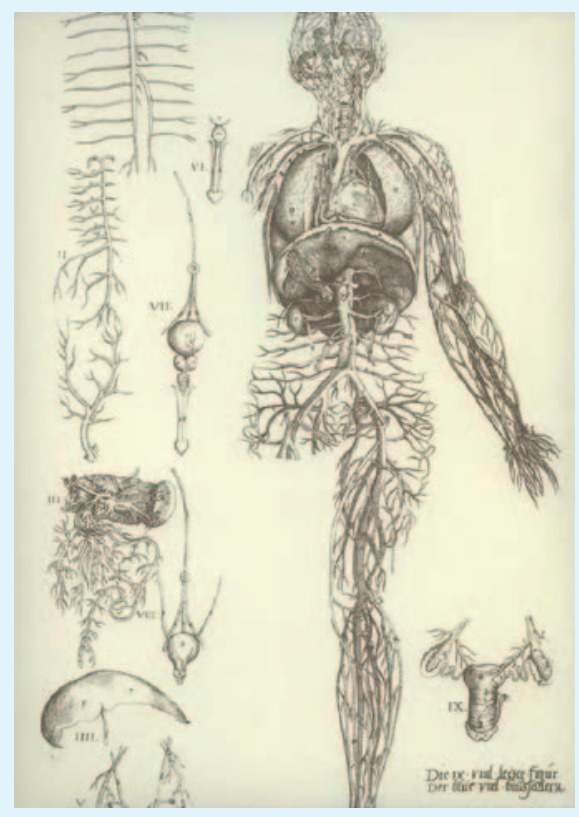

Fig. 10. The diaphragm with internal organs above and beneath From Andreas Vesalius' 'De Humani Corporis Fabrica', Basel, 1543 [18]. The topography depicted here corresponds roughly to that described in Chapter 10 of the acupuncture classic Ling-Shu Jing [2].

The points visible on its surface are in fact open holes (foramina). Together with the statue Wang Wei-Yi published a textbook on topographic and anatomic features of the vessel courses and acupuncture foramina. This text was chiselled into stone plates that were rediscovered in Beijing in the early nineteen-seventies when a new subway tube next to the old Imperial Palace was under construction (fig. 8-10) [13, 14].

\section{Practical Consequences for Clinical Acupuncture}

When we pierce the point named in the West 'Large intestine 4' with a needle as shown on figure 11 we are dealing with well-defined body structures, namely:

- The skin and the subcutaneous tissues,

- the venous network on the dorsum of the hand,

- the dorsal digital nerve (a branch of the radial nerve),

- the dorsal metacarpal artery,

- the first dorsal interosseous muscle,

- the first palmar interosseous muscle,

- the adductor muscle of the thumb,

- the main artery of the thumb surrounded by palmar metacarpal veins.

Transmitting pathways of needle stimulation are the radial, the median and the ulnar nerves, in addition to autonomous nerve fibres surrounding the blood vessels.

Neither 'meridians' nor 'points' are to be seen on this illustration. Why? Because such structures simply do not exist. We know that some acupuncturists have injured the structures mentioned above, a negligence resulting in vascular injury with haematoma or in neural injury leading to an impairment of nerves such as neuritis with persistent pain on the site of the needle insertion. Why?
Because such people know nothing about the basic anatomical structures they are actually dealing with.

The majority of Western acupuncturists still adhere to far-fetched theories about 'meridians', 'channels', and 'points'. They assume that 'energy' circulates within an imaginary and invisible tube system inside the human organism which modern medical research has still failed to detect.

On the second illustration of the $\mathrm{He}-\mathrm{Gu}$ [11] (fig. 12) the following structures can be distinguished:

- the second metacarpal bone,

- the lesser multangular or trapezoid bone,

- the tendons of the short and long extensor muscles of the thumb,

- the tendon of the long abductor muscle of the thumb,

- the first dorsal interosseous muscle,

- the adductor muscle of the thumb,

- the short flexor muscle of the thumb,

- the opposing muscle of the thumb,

- the first lumbrical muscle,

- the radial artery and veins,

- the radial nerve,

- the common palmar digital nerve I,

- the proper palmar digital nerve I.

\section{Conclusion}

How does acupuncture work then? The answer is: Via these well-known anatomical structures including the central and the peripheral nervous systems.

Besides, the original Chinese name for the body structures mentioned above is $\mathrm{He}-\mathrm{Gu}$ 合谷, to be translated as 'Meeting place in the Valley' which refers to the connection between the first and second metacarpal bones, namely the first dorsal interosseous muscle, the first palmar interosseous muscle, and the adductor muscle of the thumb, in addition to all other anatomical tissues involved. Western abbreviations for acupuncture structures like Large Intestine 4, Lung 5, Stomach 36, Liver 3, or Spleen 6 may help the student initially to memorize the order and sequence of acupuncture structures, but they do not convey the slightest factual and morphological let alone scientific information to the practitioner. This is a practical and scientific reason why we finally need an anatomical nomenclature for all acupuncture sites and structures we are applying in daily practice. It will certainly ensue in a safer and more successful application of acupuncture in the West. Furthermore, it will come closer to the intention of the original historic acupuncture (Zhen-Jiu 鍼炎) sources as laid out in the book Ling-Shu Jing.

\section{Disclosure Statement}

No conflict of interest. 

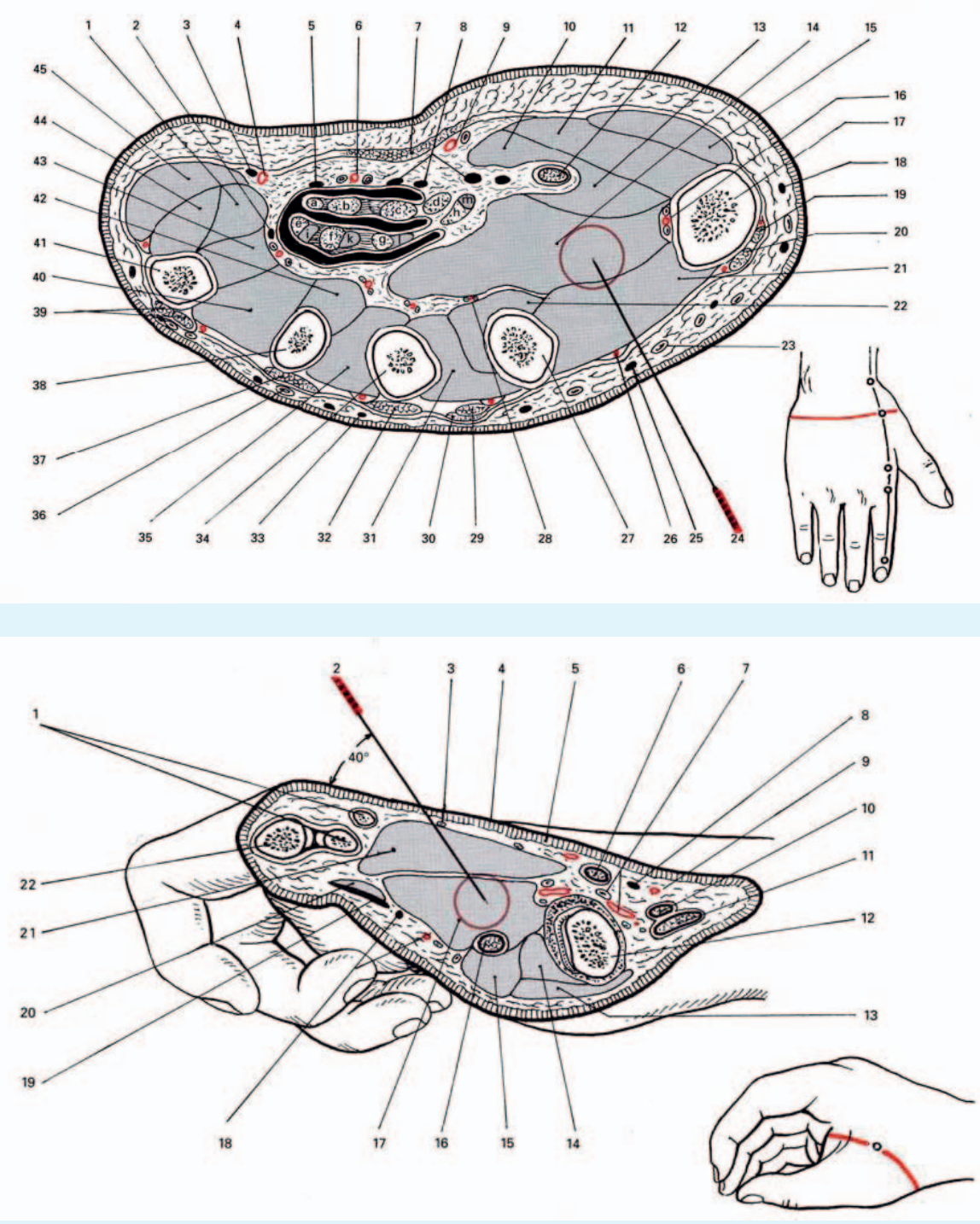

\section{References}

1 Han Annals Han Shu 漢書, Biography of Wang Mang; quoted after Chimin Wong K, Lien-Teh W: History of Chinese Medicine, Being a Chronicle of Medical Happenings in China from Ancient Times to the Present Period, ed 2. Shanghai, National Quarantine Service, 1936, pp 194-196.

2 Huang-Di Nei-Jing Ling-Shu, 黃帝內經靈樞, original edition, Wuhan/China, 1852 (and modern editions).

3 Han Annals Han Shu 漢書, Biography of Wang Mang; quoted after Chimin Wong K, Lien-Teh W: History of Chinese Medicine, Being a Chronicle of Medical Happenings in China from Ancient Times to the Present Period, ed 2. Shanghai, National Quarantine Service, 1936, pp 196-197.

4 Huang-Di Nei-Jing Su-Wen, 黃帝內經素問, original edition, Soochow/China, 1892 (and modern editions)

5 Ogawa T: The beginnings of anatomy in Japan. Okajimas Folia Anat Jpn 1975;52:59-72.

6 Ogawa T: History of Medicine (in Japanese). 1964.
7 Chimin Wong K, Lien-Teh W: History of Chinese Medicine. Being a Chronicle of Medical Happenings in China from Ancient Times to the Present Period, ed 2. Shanghai, National Quarantine Service, 1936.

8 Zhonghua Yishi Zazhi, 中華醫史雜誌, Chinese Journal of Medical History. 1994;24:68-74.

9 Feneis H, Dauber W: Tu-Jie Ren-Ti Jie-PouXue Shou-Ce 圖解人體解剖學手册, Handbook of Human Anatomical Science (in Chinese). Stuttgart, Thieme/Ho-Chi, 2001.

10 Kendall D: DAO of Chinese Medicine, Understanding an Ancient Healing Art. Hong Kong, Oxford University Press, 2002.

11 Schnorrenberger CC: Compendium Anatomicum Acupuncturae, Textbook and Atlas of Anatomical Structures of Acupuncture (in cooperation with Professor Hongchien Ha M.D.) (in German). Berlin, Walter de Gruyter, 1996.

12 Wieger W: Chinese Characters. Their Origin, Etymology, History, Classification and Signification. New York, Paragon Book Reprint Corp.; New York, Dover Publications Inc., 1965.
Fig. 11. Illustration of the $H e-G u$ foramen with a needle in situ [11]. The red circle shows the so-called target structure for the needle insertion.

Fig. 12. Illustration of the $\mathrm{He}-\mathrm{Gu}$ [11].
13 Hongchien Ha: Personal communication.

14 Hongchien Ha: A Survey on Bronze Statue of Acupuncture. China Medical College Annual Bulletin 1988;14.

15 Schnorrenberger CC: Morphological foundations of acupuncture, an anatomical nomenclature of acupuncture structures. Acupunct Med 1996;14:89-103.

16 Wang Wei-Yi: Tong-Ren Zhen-Jiu Shu-Xue TuJing. The Classical Text Attached to the Illustrations of Acupuncture and Moxibustion Points on the Tong Ren, around 1027 in the Northern Song-Dynasty (960-1126); in Zhong-Cuo Yi-Xue Da-Cheng (The Great Collection of Chinese Medicine). Shanghai, Shanghai $D a$ Dong Shu-Ju (Shanghai Bookstore of the Great East), 1936-1937.

17 Yuan Chang-Ke: Jing-Xue Hui-Jie 經穴會解, Summary and Explanation of Acupuncture Vessel Points, Japan 1854 (in Chinese). Beijing, Gu-Ji Chu-Ban-She, 1982, pp 102-104.

18 Vesalius A: De Humani Corporis Fabrica. Basel, 1543. 